This item was submitted to Loughborough's Research Repository by the author.

Items in Figshare are protected by copyright, with all rights reserved, unless otherwise indicated.

\title{
Towards an understanding of configurational and national influences on international integration in the HR function in MNCs
}

\section{PLEASE CITE THE PUBLISHED VERSION}

https://doi.org/10.1080/09585192.2020.1771399

\section{PUBLISHER}

Taylor and Francis

\section{VERSION}

AM (Accepted Manuscript)

\section{PUBLISHER STATEMENT}

This is an Accepted Manuscript of an article published by Taylor \& Francis in International Journal of Human Resource Management on 27 May 2020, available online: https://doi.org/10.1080/09585192.2020.1771399

\section{LICENCE}

CC BY-NC-ND 4.0

\section{REPOSITORY RECORD}

Edwards, Tony, O Tregaskis, and A McDonnell. 2020. "Towards an Understanding of Configurational and National Influences on International Integration in the HR Function in Mncs". Loughborough University. https://hdl.handle.net/2134/13337054.v1. 


\title{
Towards an understanding of configurational and national influences on international integration in the HR function in MNCs
}

\begin{abstract}
The human resource (HR) function plays a critical role in how multinational companies (MNCs) centralise decision-making or coordinate and exploit expertise internationally. However, there has been limited attention on the extent to which the HR function in MNCs is integrated internationally and the influencing factors behind this. Using nationally representative, cross-country comparative data, this paper identifies the degree to which internationally integrated HR functions exist and test the extent to which this is shaped by the strategy, structure and nationality of the MNC. We demonstrate the multidimensionality of an internationally integrated HR function; with the structural configuration, level of interdependencies between MNC operations and country of origin each partially impacting its nature. A key implication concerns the need to move beyond solely focusing on either nationality as per institutionalist theory, or corporate strategy and structure as characterised in the strategic international HRM literature, towards an integrated explanation that incorporates both sets of factors.
\end{abstract}

\section{KEYWORDS}

Multinationals, HR function, strategy, structure, nationality 


\section{INTRODUCTION}

In managing their international workforces, multinational companies (MNCs) face a dilemma between devolving responsibilities and resources to a local or national level or building an internationally integrated HR function. Despite the apparent importance of the international HR function for the ability of MNCs to centralize decision-making or to the ability of the firm to coordinate knowledge and expertise internationally, we have limited understanding of how the HR function is joined up internationally and the factors influencing this (Smale, Bjorkman and Sumelius, 2012; Belizon, Morley and Gunnigle, 2016). Drawing from Kim, Park and Prescott (2003), we define an internationally integrated HR function as one where control and coordination mechanisms are utilised to achieve greater consistency in the HR philosophy, policies and practices in the MNC's network of subsidiaries. However, the extent to which MNCs possess internationally integrated HR functions has not been validated through empirical research, nor have the sources of variation across MNCs been convincingly established. Accordingly, there is a need for more systematic research on the extent to which MNCs use HR integrating mechanisms in different countries (Smale, 2008) and the factors which help explain the patterns across subsidiaries (Smale, Bjorkman and Sumelius, 2013). This paper attends to this call.

An initial step in this regard is to establish the nature of HR function integration in MNCs. The literature is suggestive of strong motivations for MNCs to build a HR function that can integrate activities across geographically and culturally diverse locations, but there is limited understanding of what such a function actually consists of. Thus, we seek to identify the different types of integration mechanisms of an internationally integrated HR function and ascertain the extent to which these mechanisms are widespread across MNCs.

Having established this, we can address the principal research question, namely why is there variation across MNCs in the extent to which they have an internationally integrated HR 
function? We are interested in determining the extent to which international integration in HR flows from the strategy and structure of the firm, or the national context in which it develops, or both. The former set of factors constitute a key influence on how human resources are mobilised across a firm's international operations; the latter is a key influence on the HR capacities that firms can develop. Accordingly, we adapt and test ideas from two alternate bodies of work: first that concerning strategic international HRM (SIHRM) (e.g. Schuler et al., 1993; Schuler and Tarique, 2007; Taylor, Beechler and Napier 1996) which addresses the ways in which the HR function operates within strategic and structural features of the firm; and second, scholarship that theorises the 'embeddedness' of MNCs in their 'country of origin' (e.g. Almond, 2011; Ferner, 1997) in which the international HR (IHR) function is seen as reflecting the institutional resources and constraints from the country in which the MNC originated. These two approaches have been prominent in the literature but have largely been treated in isolation from one another and our approach allows us to generate two sets of hypotheses concerning both the configuration and structure of the multinational and its nationality of origin. Specifically, we test the effects of one set in the presence of the other, something that has not been done before. Investigating these twin influences on the nature of the IHR function in terms of the different types of integrating mechanisms allows us to establish whether they exert independent effects. A key contribution stemming from our approach is that it moves beyond overly simplistic assumptions that business strategy heavily shapes organisational HR in full isolation to its institutional environment.

The paper uses data drawn from parallel, nationally representative surveys of more than $800 \mathrm{MNCs}$ in Ireland, Spain and the UK, representing the most comprehensive test of the extent to which MNCs seek to implement internationally integrated HR functions. Each country is a major recipient and source of foreign direct investment (FDI), an important condition for examining MNCs. In 2015, inward FDI stocks as a percentage of GDP were $45 \%$ in Spain, 
$51 \%$ in the UK and $183 \%$ in Ireland against an average of $37 \%$ for developed economies as a whole. The stocks of outward FDI have increased in all three countries; between 1990 and 2015 they increased more than seven-fold in the UK (to the second highest level, behind only the US), eight-fold in Spain and eleven-fold in Ireland (UNCTAD, 2016). The importance of FDI is, therefore, a common element of all three countries and constitutes one reason why these countries are included in the study, but they have also been chosen because of the ways in which they are similar and different in terms of their institutions. Comparison between the UK and Ireland lends itself to a 'most similar research design' in which the cases share many characteristics (Djelic, 1998). Both countries offer an essentially 'liberal' business system and have had 'voluntaristic' systems of industrial relations (IR) and 'single channel' forms of employee representation, in which trade unions provide the sole means of consultation and negotiation. Spain introduces a greater degree of difference into the research design, particularly a stronger degree of regulation and state intervention, a complex web of legal regulations that ostensibly constrain MNCs' employment practices and a dual channel system of representation characterised by the co-existence of trade unions and works councils and by mandatory rights to consultation within firms. By so doing the potential for a most similar research design 'to systematically bias research by favouring some forms of explanation at the expense of others' (Wailes, 1999: 1024) can be avoided. Thus our choice of host counties allows us to balance the advantages to be gained from a most similar design by including the UK and Ireland (two countries that share many similarities in terms of institutional context) and those to be gained from a most different design by including Spain (which exhibits notable institutional differences from the other two countries). Consequently, they are appropriate contexts in which to study the activities of MNCs and the nature of HR integration.

\section{INTEGRATING HR IN MNCs}


Global integration is a key element of the 'transnational' firm which is one of the most prescribed MNC configurations (Bartlett and Ghoshal, 1989; Harzing, 2000). This configuration sees the MNC being both nationally responsive and globally effective in its operations. This is generally viewed as incorporating control and coordination tools that assist the MNC in achieving consistency across their subsidiaries (Kim et al., 2003; Smale, 2008). Control tools are vertical in nature and relate to processes that seek to govern other actors or organisations (Baliga and Jaeger, 1984). In contrast, coordination refers to horizontal mechanisms that focus on linking or aligning different parts of the organisation together to achieve a collective objective (Martinez and Jarillo, 1989). There is evidence that many MNCs seek to integrate activities across geographically and culturally diverse locations (Harzing and Sorge, 2003; Kim et al., 2003; Morris et al., 2009) which 'becomes possible only through the use of organizational mechanisms for coordination and control' (Kim et al., 2003, p. 329). Less consideration has been given to global integration at the business function level, for example HR (Smale et al., 2012) and global sourcing (Hartmann, Trautmann and Jahns, 2008). The lack of consideration in HR is somewhat surprising given the arguments indicating international HR practices play a critical role in the coordination and control capability of MNCs (Festing and Eidems, 2011; Holtbrugge and Mohr, 2011). The early work of Bartlett and Ghoshal (1989) suggests that HR needs to be integrated so as to create cohesion across operations if the transnational configuration is to be achieved. This raises key questions including just how integrated $\mathrm{HR}$ is across the operations of MNCs? and what an internationally integrated HR function looks like in practice?

MNCs have several options or approaches available to them to integrate operations and business activities. In the literature these tend to be clustered around three or four approaches (see, for example, Kim et al., 2003). The first approach is based around centralisation. This involves the most direct form of control whereby primary decision-making authority resides 
within the corporate, or regional HQ rather than at the subsidiary level. There is therefore constrained capacity and ability for local level adaptation with the corporate HQ more likely to determine items such as senior managerial pay, recruitment and development of senior managers, and other financially important issues (e.g. headcount). The importance of 'common platforms or guidelines' for MNCs seeking to replicate or integrate HR practices has been noted within this approach (Morris et al., 2009, p. 976). One type of platform is where the corporate headquarters develops an overarching philosophy that frames how HR issues are handled worldwide and establishes a body capable of specifying more detailed policies (Schuler, Dowling and De Cieri 1993; Wächter et al. 2006). Subsidiaries are likely to have varying degrees of autonomy over the development of HR practices within the remit of an overarching corporate HR philosophy (Belizon et al., 2016), which can assist in the alignment and achievement of goals and objectives though providing guidance on desired behaviour and practice (Morris et al., 2009). As such, it can be said that varying degrees of centralisation may exist. If such a philosophy becomes a shared vision then the MNC's ability to share and integrate knowledge increases (Tsai and Ghoshal, 1998).

The second approach is whereby people or personal-based modes are incorporated to integrate operations. The use of expatriates in MNCs is an especially important mechanism of coordination and control. Arguably, other types of direct social mechanisms may have greater applicability in the HR domain than the use of expatriates (Evans, Pucik and Bjorkman, 2011). The focus may be more centred on bringing relevant HR professionals together in fora to discuss, develop and diffuse HR policies and practices. In other words, HR practice integration may more commonly be enabled 'through the use of global or regional HR committees and steering groups that bring HR managers together to discuss HR-related concerns' (Smale, 2008, p. 138). Interactions between unit and corporate HR actors may play a critical role in developing and coordinating the overall HR capability base of MNCs, providing fora to share 
knowledge and develop a common understanding of how HRM and subsidiaries are linked to corporate strategy (Ferner et al., 2011). A potentially important by-product of using peoplebased mechanisms is that increased engagement between corporate and subsidiary actors may develop trust between actors, a key enabler of knowledge-sharing (Willem, Buelens and Scarbrough, 2006). Consequently, in line with the people-based perspective, an internationally integrated HR function may be characterised by a high degree of cross-country networking between HR practitioners (Farndale and Paauwe, 2005).

A formalisation-based approach consists of mechanisms that focus on the codification or standardisation of HR practices and policies at the international level. This is therefore a more detached and bureaucratic form (Harzing and Sorge, 2003) with emerging evidence (e.g. Smale's, 2008) indicating that formalisation mechanisms are the most commonly used means for achieving HRM integration. It is common that units are required to report to HQs on various aspects of HR (Ferner et al., 2011) and as such they permit 'behavioural and process control' to exist (Smale et al, 2013, p. 235). Such mechanisms are manifest, for example, through the development of common HR structures and frameworks (Tempel, 2001) or directly reporting HR issues from units to the headquarters (Belizon et al., 2013; Ferner et al., 2011). The rise of HR 'shared services' centres that see organisations concentrating particular HR activities in one location represents an additional, more recent avenue for integration, knowledge sharing, replication and cost savings (Cooke, 2006). These centres act as a formalization-based approach by providing 'HR services to subsidiaries through treating them as internal customers' (Belizon et al., 2016, p. 544).

The final mode is the information-based approach although this is sometimes subsumed under the formalisation approach (e.g. Smale, 2008; Smale et al., 2012). Information-based mechanisms focus on the flow of knowledge through simple database applications and/or more sophisticated IT platforms. Formal IT systems are useful in the sharing of codifiable and easily 
transferable knowledge, but more complex knowledge sharing requires more lateral formal mechanisms of coordination (Willem et al., 2006). IT processes that record information on key resources, such as the identification of talented staff capable of filling international management roles (Novicevic and Harvey, 2001; Sparrow, 2007), represent another means for facilitating coordination and integration across borders. As Morris and colleagues put it:

'.... the use of [aligned IT systems in subsidiaries] allows individuals easier and quicker access to one another, and .....codifies and embeds ideas agreed upon by spatially distant people and groups that would normally have a difficult time frequently discussing these issues (Morris et al., 2009: 977-978)

The options by which MNCs can integrate their operations globally is therefore varied and multifaceted. People-based mechanisms appear to be uniformly used for international integration, while centralisation has been suggested as a corporate level approach that has a trigger effect on the other mechanisms (Belizon, Morley and Gunnigle, 2016). For example, if the MNC seeks to centralise the locus of decision making then international structures are more likely to exist (Smale et al., 2013). The literature has been useful in identifying possible components of an international HR function but the limited coverage of this research provides minimal indications concerning what is most prevalent. There is also a knowledge lacuna surrounding the relationship between these components. In order to develop our understanding of the role of the international HR function, in the following sections we consider the consistency in the relationship between the different elements of the international HR function and wider organisational structural and national factors.

\section{CONFIGURING THE INTERNATIONAL HR FUNCTION}

Most models of SIHRM assume that a firm's approach to HR is shaped by its wider business strategy. For example, Schuler et al. (1993, p. 449) argue that there is evidence to see 
'a common approach to managing human resources as a function of the competitive strategy' of the MNC. In parallel with business strategy, the SIHRM strategy and linked structures should also evolve, with firms new to the global stage most likely to exert a strong controlling HQ role (Evans et al. 2011). In this vein, Taylor et al. (1996, p. 968) argue that 'for firms that are changing from a multi-domestic to a global strategy, the demands for internal consistency will generally outweigh the demands for local responsiveness' leading to an 'integrative SIHRM orientation'. For MNCs pursuing a global strategy it is expected that significant emphasis is placed on mechanisms that facilitate strong international HR integration. Moreover, Schuler and Tarique (2007) highlight the importance of vertical alignment whereby the HRM structures and practices support the internal (e.g. corporate strategy, values) and external contextual factors (e.g. political and cultural environment).

In formulating expected linkages between business strategy and SIHRM we identify various arenas in which integration within the multinational firm can occur (Edwards, Marginson and Ferner, 2013). One is the strategy of the firm and how it is configured, including the extent to which the functions of operations in different countries are similar or different and the ways in which business activities are inter-linked cross-nationally. A second relates to internal operating structures, including forms of international management organization. And a third concerns how functions, such as HR, are organized at the international level. So how will the first and second order issues affect the third?

A critical aspect of the first issue concerning configuration is the extent to which MNCs create an inter-dependent network of sites. There is evidence of many MNCs moving towards internationally integrated manufacturing or service provision (e.g. Edwards 2011). In such MNCs, one set of national operations may supply others or be supplied by others, with production or service provision taking the form of an international network in which resources and capabilities are distributed across the firms' operations internationally (e.g. Malnight 1996; 
Watson O'Donnell 2000). If there is variation in the extent to which MNCs establish interdependent networks - as is likely given the different sectoral conditions concerning the logistical issues in transporting semi-finished goods and components - then there is variation in the implications for the nature of the IHR function. Specifically, the stronger the interdependency in production, the stronger the incentive for some aspects of HR to be coordinated internationally. For example, these firms may seek to establish internationally mobile teams capable of ensuring the smooth exchange of components and knowledge across countries, while they may also be vulnerable to disruption from local disputes and see ensuring consistency in practice across borders as a way of avoiding such disputes (Edwards 2011). These factors suggest that strong integration at the first order level of the configuration of the production network creates pressures for an integrated HR function across the MNC. On the other hand, there will be fewer pressures for an integrated HR function amongst companies where subsidiaries predominantly serve local markets utilising their own domestic supply chain. Thus, we propose that:

H1: Inter-dependencies in production across borders will be positively associated with a) centralization - based modes; b) people-based modes and c) formalization / information based modes of integration within the HR function.

Firms configuring themselves through an inter-dependent network are likely to have international management structures, at either regional or global levels, linking the same activity internationally and providing organizational channels for implementing such strategies (Farndale et al. 2010). The existence of such international structures can deepen contact between managers and key staff across countries, thereby assisting in the transmission of information across borders within HR (Taylor et al. 1996). Where international structures promote two-way transfer of knowledge across networks, this can enable the development of 
a core MNC capability and be a key source of competitive advantage (Kogut and Zander 1993), thus promoting the potential benefits of an integrated IHR function. Brewster, Sparrow and Harris (2005, p. 962) found that 'HR departments are taking on responsibility for the conscious development of operating networks, both as practitioners within the HR community and as facilitators elsewhere in the organization'. As well as facilitating intra-MNC networking, international structures may also create a locus of authority within the multinational that has knock-on effects on the HR function (Edwards, 2011). We might therefore expect MNCs in which corporate structures have an international dimension - be it regionally or globally - to possess a stronger international element to the organization of the HR function. This leads us to propose that:

H2: Compared to national structures, regional or global corporate structures will be positively associated with a) centralization - based modes; b) people-based modes and c) formalization / information - based modes of integration within the HR function.

\section{THE NATIONALLY EMBEDDED NATURE OF THE IHR FUNCTION}

The way in which MNCs arrive at these forms of integration is influenced by their embeddedness in multiple national environments. Despite globalisation, MNCs remain concentrated in the home country in numerous ways (Ferner 1997). While it is conceivable that MNCs may develop international modes of organization which are not influenced by their original business system, there are barriers to such a development that result in this being rare in practice (e.g. Heidenreich 2012). The embeddedness of MNCs in their original country creates a 'country of origin' effect (Ferner 1997) whereby MNCs tend to exploit, deliberately or otherwise, the resources afforded by this context (Smale 2008).

There are grounds for anticipating that US MNCs will have strong structures in place to promote an internationally integrated HR function. As Ferner et al. (2004) argue, the typical 
management systems in US firms allow control to be exercised from a strategic centre over geographically dispersed operations and these can relatively easily be extended to the international level as they do not rely on tacit knowledge, thus centralized-based integration modes are expected to be common. Moreover, the perceived 'dominance' of the US economy creates a mentality among senior staff in US MNCs that the structures and practices developed at home should be extended to cover other countries (Ferner et al., 2004). Specifically in relation to the HR function, many US firms have been characterised by innovative people management approaches, such as the 'welfare capitalist' approach of firms like Kodak and Sears (Jacoby 1997) or the 'low-road' style of McDonalds and WalMart (Royle 2010), both of which are forms of keeping unionization at bay. Such approaches to managing their workforce 'may well provide the capability for a strategic, centralized approach to international human resource management' (Ferner et al 2004, p. 367). Case study evidence has pointed to many US MNCs having exported HR structures and tools such as policy-making committees and shared service centres (Wächter et al. 2006).

The capability and inclination of MNCs of other nationalities to implement strongly coordinated international HR functions appears somewhat lower. The evidence concerning Japanese MNCs suggests that they share with US MNCs a preference for a strong central influence on some aspects of IHR but that they approach this differently. Japanese MNCs tend to have a strong preference for personal or people-based mechanisms, specifically through sending expatriates from Japan to fill key positions abroad. A range of studies have shown that Japanese MNCs are distinctive in their use of 'parent country nationals' in staffing leadership positions in their subsidiaries (Belderbos \& Heijltjes, 2005; Harzing, Pudelko \& Reiche, 2016; Tung 1982). These expatriates appear to be extensively deployed in order to integrate and control operations, playing a part in over-seeing the implementation of a distinctive production system and its associated employment practices (Colakoglu and Caligiuri 2008). 
German MNCs also appear to lack the IHR structures that US MNCs exhibit, though for different reasons. The function in Germany is characterised by a 'highly reactive, administrative style of personnel management rooted in a specifically German institutional framework' (Ferner and Varul 2000, p. 92) with the work of personnel specialists having become highly 'juridified', revolving to a great extent around dealing with codetermination, administering legal regulations and implementing elements of collective agreements arrived at levels above the firm. Therefore, forging a strategic identity at the international level has been difficult for a function embedded in the German context. It is therefore unsurprising that contact between the corporate HR function in German MNCs and their freeing operations have tended to be ad hoc and minimalist (Ferner and Varul 2000).

The evidence concerning other nationalities of MNCs is patchier. The domestic context of UK MNCs shares some features with the US, notably a broadly 'liberal' business system and a patchy coverage of collective representation. However, it differs in important respects. Historically, British MNCs have exhibited weaknesses in management and organizational structures which impeded the exercise of control over overseas operations' (Wilson 1995, p. 111). More specifically, the antipathy towards professional management training and traditions of 'gentlemanly capitalism' contributed to a 'cult of the amateur' among managers in British MNCs, contrasting sharply with the development of professionalised management functions and structures among US firms (Gospel 1992; Wilson, 1995). This suggests that British MNCs have lacked the corporate resources on which a highly integrated IHR function might be based. This problem also pertains to French MNCs, which are traditionally viewed as being highly bureaucratic and centralized (Thory 2008). There is some limited evidence of international managerial networking and restructuring by drawing on the practices employed in their foreign subsidiaries (Mtar 2010; Thory 2008). The foreign operations have, in some cases, been utilised 
as a means to move away from the traditional centralized and rigid forms of control typical of French MNCs.

Overall, this analysis leads us to hypothesise that:

H3: US MNCs are more likely than those of other nationalities to use a) centralizationbased modes; b) people-based modes and c) formalization / information - based modes of integration within the HR function.

A visual summary of the hypotheses is contained in Figure 1.

\section{INSERT FIGURE 1 ABOUT HERE}

\section{METHOD}

The dataset consists of a co-ordinated series of nationally representative surveys of employment policies and practices in MNCs. This paper is based on surveys conducted in Ireland, Spain and the UK. A structured questionnaire was administered through a face-to-face interview (a method that permits a lengthy questionnaire to be administered with very little non-response) with the most senior HR executive who was capable of describing HR policy and practice in the national operations, as well as the HR structures of the wider MNC. The questionnaire was designed in English, translated into Spanish and these translations were carefully checked in order to ascertain that equivalence in meaning had not been distorted through language translation (Hult et al 2008). The questionnaires were developed through a strong collaborative process between the different country researchers and were piloted in each country.

Each survey was representative of the population of MNCs in that country, comprising both foreign and domestically owned MNCs. We focussed on all but the smallest MNCs, defined as those with less than 100 employees in the survey country or less than 500 worldwide 
for foreign-owned firms; those with less than 100 outside the country of origin or less than 500 worldwide for domestically-owned firms. We omitted these small firms because they tend not to have an HR function as such, relying instead on an individual or even buying in HR support. Crucially, in order to ensure representativeness, we constructed a population listing through multiple databases and resolved discrepancies through labour-intensive cross-checking and recourse to company websites, something that very few surveys in this area appear to do. Moreover, the resulting population listing was 'screened' through a short telephone survey to check crucial aspects, a time-consuming process but an important one; it revealed that many companies were smaller than the initial listing had suggested, while others were a part of the same MNC as another firm in the national listing. We placed significant importance on this stage to ensure that the data would be collected from comprehensive and reliable population listings, something uncommon in international HRM research (see Authors for further detail on the development of the population and overall study).

The response rates varied from $18 \%$ in the UK, $30 \%$ in Spain to over $50 \%$ in Ireland. Given the overall size of the MNC population in each country, the overall numbers of participating firms in each country did not vary substantially. Detailed work was undertaken to create robust sampling frames of the MNCs within each country and to assure the sample accurately reflected the size and sectoral distribution of firms nationally. The total number of MNCs across the three countries was 832 with listwise deletion.

\section{$\underline{\text { Measures }}$}

\section{Dependent variable}

An internationally integrated HR function is multidimensional in nature. Drawing strongly from the approach of Kim et al. (2003) and Smale et al (2012) we include eight dummy variables measuring centralisation, people-based and formalisation/information-based 
integration mechanisms. The construct validity of this theoretically derived measure was scrutinized using Confirmatory Factor Analysis (CFA). The measures thus included:

- Two variables measured transnational policy and philosophy, representing the centralisation-based mechanisms: one was measured using a yes $=1$ and no $=0$ response because it recorded the existence or otherwise of an IHR committee that developed global HR policy. The second used a 1-5 response option to capture the strength of the global HR philosophy. Respondents were asked the extent to which they agreed that there was a global HR philosophy concerning the management style toward employees. Responses were measured on a scale ranging from 1 (strongly disagree) to 5 (strongly agree).

- To operationalise the people-based integration mechanism we utilised four dummy variables which measured the extent of networking within the HR function, relating to bringing together HR professionals from different countries through regular crossborder meetings, international HR conferences, task forces and virtual project teams.

- For the formalisation/information categorisation we used two dummy variables, namely the existence of an international HR Information System (IHRIS) and international shared services centre.

CFA was used to test this 3-factor solution using the statistical package MPlus with robust methods to take account of the variation in the ordered nature of the data i.e. the use of dummy variables and 1-5 interval variables (Kline 2004). The results were supportive with all variables loading on the factors in the hypothesised direction and significant at the p .001 level. Further, 
the values for the fit indices exceed thresholds for acceptable model fit (Byrne 2006): $\chi^{2}$ 1076.92; df 28; $p>.05 ; \mathrm{n}=892$; RMSEA .026; CFI .991 (i.e. The Satorra-Bentler rescaled $\chi^{2}$ is nonsignificant indicating good fit with the data). The non-normed fit index (NNFI) and the comparative fit index (CFI) exceed .90 and .95 respectively indicating good fit (Byrne, 2006). Thus, we find validity for the adoption of three latent variables measuring different aspects of international HR integration. The correlation matrix in Appendix 1 confirms the strong interrelationship between these 3 latent variables, but importantly, the CFA and fit indices also demonstrate that the 3 latent variables are each measuring something distinct. Thus, as we argued theoretically, there is value in measuring international HR integration as a multidimensional construct. In the subsequent regression analysis, we use the 3 latent variables reflecting informational-based, people-based and centralised-based methods of international HR integration. The correlation matrix in Appendix 1 shows the relationship between these latent variables and independent variables.

\section{Independent variables}

The 'first-order' issues of strategy and structure were measured as follows:

- Intra-firm dependencies in production: assessed through one variable which captured the presence of intra-firm trading links: 0 indicated no inter-dependencies existed, 1 indicated the subsidiary either was supplied by or supplied to other subsidiaries and 2 indicated subsidiaries were both supplied by and supplied to other subsidiaries. In deciding to use binary or ordered variables we considered the alternative of using scales on this issue (e.g. Mauri and Phatak, 2001). However, during the piloting process it became apparent that gaining accurate data from HR respondents on items like the percentage of output that is subject to intra-enterprise trade would yield excessive missing data. 
- Structures: assessed by asking if firms were organised along global structures, regional world structures or national (country) structures. Responses were dummy coded into three variables - global, regional, national structures (reference category).

- Country of origin: measured through twelve categories: US (reference category), UK, Germany, France, Nordic, Swiss, Spain, Ireland, Netherlands, Japan, Rest of Europe, and Rest of World. The choice of US firms as the reference category is derived from the theoretical arguments supporting the distinctiveness of US firms arising from 'dominance' effects, as set out in the introduction.

\section{Controls}

- Home-owned: we controlled for whether firms were home owned or foreign owned to take into account HR and strategic co-ordination structures that might be associated with two types of firms (Egelhoff 1984). We captured this using a dummy variable, with 1 indicating the firm was home-owned.

- Country of operation: operationalised through three dummy variables representing each country in which the survey took place. We included this control to account for variation between the three institutional contexts, such as patterns of legal regulation, that might impact on the type of FDI attracted to a country which can influence the international strategy of firms and their degree of localisation-globalisation (Almond, Ferner and Tregaskis, 2015).

- Sector: was included as a control because the nature of technologies and key aspects of the product market vary between broad industrial sector and these factors may shape the degree of 
co-ordination across geographical locations. We captured this through one dummy variable with 1 indicating production and 0 services.

- Size: was measured through 4 dummy variables capturing the worldwide employment in the MNC: 500-4999 (reference category), 5000-29999, 30000-59999, and 60000+. These data were collected via categorical questions rather than by asking for a specific figure as respondents indicated during piloting that they found it difficult to give exact figures on worldwide employment. Larger firms are expected to be more likely to use all IHR integrating mechanism because they have the resources available and the logistical capabilities to coordinate (Ferner et al. 2004).

INSERT TABLE 1 HERE

Analysis

The hypotheses were tested by regression analysis using SEM through MPlus which allowed for the use of robust statistics and regression of the independent variables on the three latent variables measuring the International HR function. Running the regression analysis through structural equation modelling allows us to estimate each equation simultaneously, moreover residuals in the dependent variables were allowed to correlate thus any remaining associations within the dependent variables were controlled for. We also included the four control variables because of the likely impact these would have on the dependent variable.

\section{RESULTS}

Means and standard deviations for all variables are provided in Table 1. A correlation matrix is available in the appendix. Table 2 shows the results for the regression analysis. As 
anticipated, the control variables had an important influence on IHR mechanisms. The size of the firm had a consistent impact, with larger firms more likely to have IHR mechanisms of all three forms. The effect of the other controls varied across the different integration modes, however. Sector was only significant with respect to the use of the formalisation / information mode i.e. service sector firms were more likely to adopt the formalisation/information mode compared to production. The country of operation was not relevant to the use of the peoplebased mode, but centralised IHR mechanisms were more likely to be used among MNCs operating in Spain. Furthermore, formalisation / information modes were more commonly used by MNCs in Spain and the UK than those in Ireland.

After controlling for these effects, the impact of organizational inter-dependencies and structure and nationality of ownership are evident. MNCs with global and / or regional structures, and those where there are inter-firm dependencies, are significantly more likely to adopt IHR structures. However, there is some variation in the influence of these organisational factors on the integration mechanisms. Specifically, firms that have inter-firm dependencies are more likely to adopt both centralisation-based and people-based mechanisms but not significantly more likely to have formalisation/information mechanisms. Concerning corporate structures, a global element to the structure is the key aspect that affects the IHR function, with this being associated with all three types of IHR mechanism. The effect of regional structures is more limited as it only has a significant effect on centralization-based modes.

Country of origin had a marked effect on the nature of integration of the IHR function. Generally, when compared with MNCs from other countries, US-owned firms are more likely to use each of the three IHR integrating mechanisms. This is most clear cut for formalization / information-based modes of integration, for which US MNCs were significantly more likely than nine of the eleven comparator groups (for Spanish and Irish MNCs the differences were in the anticipated direction but fell short of statistical significance). For the other two modes, 
US MNCs were significantly more likely to have these mechanisms than six of the eleven comparator groups; in the other five groupings, the sign was in the anticipated direction (with the exception of Irish MNCs for international networking) but the difference was not significant.

\section{INSERT TABLE 2 HERE}

The fit statistics show that the model results are strong and the percentage of variance in the dependent variables explained by the independent variables is high: $27 \%$ accounted for in the people-based measure, $44 \%$ of the variance accounted for in the centralization measure and $57 \%$ of the variance accounted for in the formalization / information measure.

In sum, the first set of hypotheses related to the impact of inter-dependencies in production on the IHR function. We found support for the impact of this factor on centralization-based (H1a) and people-based (H1b) mechanisms in the IHR function. The results for formalization/information-based mechanisms were not significant, so H1c is not supported. The second set of hypotheses concerned the influence of regional or global elements to the corporate structure on the IHR function. A global element to the corporate structure was positively associated with all three types of international integration in HR, providing support for $\mathrm{H} 2 \mathrm{a}, \mathrm{H} 2 \mathrm{~b}$ and $\mathrm{H} 2 \mathrm{c}$. A regional element was also positively associated with centralizationbased mechanisms of integration, providing further support for $\mathrm{H} 2 \mathrm{a}$, though the relationship with the people and formalization / information-based mechanisms was not significant. The third set of hypotheses contended that the HR function will be more internationally integrated in US MNCs compared to those of other nationalities. The results demonstrated strong support for this contention. All but one of the national groupings are less likely than US MNCs to have 
an internationally integrated HR function, in some cases across the board, in other cases at least to some extent and so we accept $\mathrm{H} 3 \mathrm{a}, \mathrm{H} 3 \mathrm{~b}$ and $\mathrm{H} 3 \mathrm{c}$.

\section{DISCUSSION \& CONCLUSION}

The analysis began with an analysis of the different components of the international HR function which enabled us address the criticism of Smale et al. (2013) who noted the failure to encompass a broad range of integration mechanisms in previous research studies. We have demonstrated that an integrated HR function is multidimensional, consisting of centralization, people- and formalization / information-based mechanisms. We then tested hypotheses concerning the factors that influence these.

The results suggest that in general, both inter-dependencies and global/regional organisational structures were key explanatory factors in the adoption of international HR modes of organising, however, their effects were not uniform. Our interpretation of this is that it reinforces the notion that the HR function in MNCs is partially, rather than fully, nested within organisational configuration and structure. As has been argued elsewhere: 'Partial nesting of third-order HR structures, control practices and policy approach within first- and second-order international configuration implies that the former are not fully determined by the latter; they operate according to a logic which is only partly connected to business strategy, operational configuration and internal structures of management organization' (Edwards, Marginson and Ferner, 2013). In analysing the factors that shape the nature of the IHR function itself we have been able to extend and refine this. The implication of the HR function being only partially linked to business strategy and corporate structure is that HR practitioners can develop the function in ways that are to some degree independent of strategy and structure; in other words, they have a degree of choice within structural constraints. 
The results for the third set of hypotheses on the distinctiveness of US MNCs confirms that the nationality of ownership significantly conditions the inclination and capabilities of firms to develop international structures in HR, and these effects do not disappear when a set of other potential influences are controlled for. In other words, nationality is not simply a reflection of organizational characteristics such as size, sector, strategy and structure; rather, it comprises institutional influences from the country of origin which endure. The clear implication is that the capabilities and orientation of HR practitioners are institutionally conditioned.

The interesting exception to this picture of national differences concerned Irish MNCs, which were not significantly less likely than US MNCs to develop an internationally integrated HR function. This may be explained by the relatively recent internationalization of Irish MNCs from a domestic base which has become heavily shaped by US capital. Thus the process of internationalization of Irish MNCs has been one in which managers in Irish MNCs looked to emulate the structures of their US counterparts, constituting a 'demonstration' effect (McDonnell, Gunnigle and Lavelle, 2014). This suggests that while the capabilities and orientation of HR practitioners are institutionally conditioned, they are not always determined by home country institutions.

Overall, our argument has been that variation in the international dimension to the HR function can be understood partly through the influence of configuration and corporate structure and partly through the influence of the institutions in the country of origin. In line with Björkman and Welch (2015) we call for a shift from overly-simplistic theorisation. Our research points to needing to move beyond a sole focus on strategy and structure that characterises some of the SIHRM literature (e.g. Schuler et al., 1993; Schuler and Tarique, 2007; Taylor, Beechler and Napier 1996) or a sole focus on the country of origin that characterises the institutionalist literature (e.g. Almond, 2011; Ferner, 1997). Analysis that 
focuses solely on strategy and structure downplays the embeddedness of these strategies and thereby risks overplaying the strategic choices that companies make. The problem with examining only national context is the opposite; it ignores the potentially important role of how strategic variation among a national group of MNCs can create diversity in the way they operate their HR function cross-nationally. By revealing that both effects are significant in the presence of the other, we can rule out the possibility that national effects are simply capturing different business strategies and structures or vice versa. This has not been shown before.

The analysis is based on a dataset with much strength - the rigour that went into establishing a population listing, administration through face-to-face interviews resulted in very little non-response, the careful translation and back translation - but there are of course some limitations, two of which stand out. First, the surveys relied on a single respondent, as key organisational informants, with the associated drawbacks. This was built into the design because we were sure that seeking a second respondent would greatly reduce the response rate. Second, the response rate was lower in the UK than in the other two countries, raising questions about the representativeness of the British data. Substantial effort was put into checks for nonresponse bias in the UK (and elsewhere), which demonstrated that this was not a problem.

The approach taken in this paper could be extended. One direction for future research would be to explore whether these patterns are the same or different in other countries, particularly those outside Europe. If Europe has become a 'distinct regulatory space' (Marginson, 2000) then do the same relationships hold in North America or Asia, for instance? A second way in which research could be advanced is through an examination of additional sources of variation among MNCs, such as the types of employees that they employ by skill levels or personal orientation and the organizational culture of the firms. This may require a more qualitative, case-based approach. A third direction for future research would be to explore whether the influence of 'higher order' issues of business strategy and corporate structure and 
the influence of national institutions are both in evidence on other HR processes. For example, are both these sets of factors significant in explaining whether MNCs develop international learning mechanisms in the HR function or whether they enhance the international mobility of this group? And a fourth possible direction for future research might be to examine the performance implications of variations in the international integration of HR. Do firms with HR functions that are highly integrated across borders exhibit favourable HR outcomes than those that are weakly integrated? Or is the relationship between the extent of integration and HR effectiveness contingent on other factors? Moreover, how much impact does the strength of particular integration mechanisms have over other configurations? Where people-based mechanisms are used, does the effectiveness of HR integration depend much on the skills sets, and competencies possessed? The answers to these questions have obvious implications for practitioners. 


\section{REFERENCES}

Almond, P. (2011) Re-visiting 'country of origin' effects on HRM in multinational corporations, Human Resource Management Journal, 21 (3), 258-271.

Almond, P., Ferner A. \& Tregaskis, O. 2015. The changing context of regional governance of FDI in England. European Urban and Regional Studies, 22, 1, 61-76.

Baliga, B. and Jaeger, A., 1984. Multinational corporations: Control systems and delegation issues. Journal of International Business Studies, 15 (2), pp.25-40.

Bartlett, C. and Ghoshal, S. 1989. Managing across Borders, Hutchinson, London.

Bartlett, C. and Ghoshal, S., 2002. Building competitive advantage through people. MIT Sloan management review, 43 (2), 34.

Belderbos, R. and Heijltjes, M. G. 2005. The determinants of expatriate staffing by Japanese multinationals in Asia: Control, learning and vertical business groups. Journal of International Business Studies, 36, 3, 341-354.

Belizon, M. J., Gunnigle, P. \& Morley, M. 2013. Determinants of central control and subsidiary autonomy in HRM: the case of foreign-owned multinational companies in Spain. Human Resource Management Journal, 23 (3), 262-278.

Belizon, M. J., Morley, M. \& Gunnigle, P. 2016. Modes of integration of human resource management practices in multinationals, Personnel Review, 45 (3), 539-556.

Björkman, I. \& Welch, P. (2015) Framing the field of international human resource management research, The International Journal of Human Resource Management, 26 (2), 136-150.

Brewster, C., Sparrow, P. \& Harris, H. 2005. Towards a new model of globalizing HRM, The International Journal of Human Resource Management, 16 (6), 949-970. 
Byrne, B. 2006. Structural Equation Modeling with EQS: Basic Concepts, Applications, and Programming, 2nd ed., Lawrence Erlbaum Associates, Inc., Mahwah, NJ.

Colakoglu, S. \& Caligiuri, P. 2008. Cultural distance, expatriate staffing and subsidiary performance: The case of US subsidiaries of multinational corporations, The International Journal of Human Resource Management, 19 (2), 223-239.

Cooke, F. L. 2006. "Modelling an HR shared services center: Experience of an MNC in the United Kingdom, Human Resource Management, 45 (2), 211-227.

Djelic, M. (1998) Exporting the American Model: The Postwar Transformation of European Business, Oxford: Oxford University Press.

Evans, P., Pucik, V. \& Barsoux, J-L. 2002. The global challenge. Frameworks for international human resource management. New York: McGraw Hill.

Edwards, T. 2011. The nature of international integration and human resource policies in multinational companies, Cambridge Journal of Economics, 35, 483-498.

Edwards, T., Marginson, P. \& Ferner, A. 2013. Multinational Companies in Cross-National Context: Integration, Differentiation and the Interactions between MNCs and Nation States, Industrial and Labor Relations Review, 66 (3), 547-587.

Egelhoff, W. 1984. Patterns of control in US, UK and European Multinational Corporations, Journal of International Business Studies 15(2): 73-84.

Evans, P., Pucik, V. \& Bjorkman, I. 2011. Global challenge: International human resource management, $2^{\text {nd }}$ edition. New York: McGraw Hill.

Farndale, E. \& Paauwe, J. 2005. The role of corporate HR functions in multinational corporations: The interplay between corporate, regional/national and plant level" (CAHRS Working Paper \#05-10). Ithaca, NY. 
Farndale, E., Paauwe, J., Morris, S., Stahl, G., Stiles, P., Trevor, J. \& Wright, P. 2010. Context-bound configurations of corporate HR functions in multinational corporations, Human Resource Management, 49 (1), 45-66.

Ferner, A. 1997. Country of origin effects and HRM in multinational companies" Human Resource Management Journal, 7 (1), 19-38.

Ferner, A., Almond, P., Clark, I., Colling, T., Edwards, T., Holden, L. \& Muller-Carmen, M. 2004. The Dynamics of Central Control and Subsidiary Autonomy in the Management of Human Resources: Case Study Evidence from U.S. MNCs in the UK, Organisation Studies, 25 (3), 363-391.

Ferner, A., Tregaskis, O., Edwards, P., Edwards, T., Marginson, P., Adam, D. and Meyer, M., 2011. HRM structures and subsidiary discretion in foreign multinationals in the UK. The International Journal of Human Resource Management, 22(03), pp.483-509.

Ferner, A. \& Varul, M. 2000. Internationalisation and the Personnel Function in German Multinationals, Human Resource Management Journal, 10 (3), 79-96.

Festing, M. and Eidems, J., 2011. A process perspective on transnational HRM systems-A dynamic capability-based analysis. Human Resource Management Review, 21(3), $162-173$.

Gospel, H. 1992. Markets, Firms and the Management of Labour in Modern Britain, Cambridge: Cambridge University Press.

Hartmann, E., Trautmann, G and Jahns, C. 2008. Organisational design implications of global sourcing: A multiple case study analysis on the application of control mechanisms, Journal of Purchasing \& Supply Chain Management, 14, 28-42. 
Harzing, A.-W. 2000. An empirical analysis and extension of the Bartlett and Ghoshal typology of multinational companies, Journal of International Business Studies, $31(1), 101-20$.

Harzing, A.-W., Pudelko, M. and Reiche, B. S. 2016. The bridging role of expatriates and inpatriates in knowledge transfer in multinational companies, Human Resource Management, 55, 4, 679-695.

Harzing, A.-W and Sorge, A. 2003. The relative impact of country of origin and universal contingencies on internationalization strategies and corporate control in multinational enterprises: worldwide and European perspectives, Organization Studies, 24 (2), 187 214.

Heidenreich, M. 2012. The Social Embeddedness of Multinational Companies: A Literature Review, Socio-Economic Review, 10 (3), 549-579.

Holtbrugge, D. \& Mohr, A. 2011. Subsidiary interdependencies and international human resource management practices in German MNCs. A resource-based view”, Management International Review, 51, 93-115.

Hult, G., Thomas M., Ketchen, D., Griffith, D., Finnegan, C., Gonzalez-Padron, T., Harmancioglu, N., Huang, Y., Berk Talay, M. and Cavusgil, S. 2008. Data equivalence in cross-cultural international business research: assessment and guidelines, Journal of International Business Studies 39 (6), 1027-1044.

Jacoby, S. 1997. Modern Manors: Welfare Capitalism Since the New Deal. Princeton, NJ: Princeton University Press.

Kim, K., Park, J.-H. \& Prescott, J. 2003. The global integration of business functions: a study of multinational businesses in integrated global industries, Journal of International Business Studies, 34 (4), 327-344. 
Kline, R. 2004. Principles and practice of structural equation modeling, 2nd ed. New York, NY: Guilford Press.

Kogut, B. \& Zander, U. 1993. Knowledge of the firm and the evolutionary theory of the multinational corporation, Journal of International Business Studies, 24 (4), 625-645.

Malnight, T. (1996) The Transition from Decentralized to Network-Based MNC Structures: An Evolutionary Perspective, Journal of International Business Studies, 27 (1), 43-65.

Marginson, P. 2000. The Eurocompany and Euro Industrial Relations", European Journal of Industrial Relations, 6 (1), 9-34.

Martinez, J. \& Jarillo, J. 1989. The evolution of research on coordination mechanisms in multinational corporations, Journal of International Business Studies, 20 (3), 489514.

Mauri, A. \& Phatak, A. 2001. Global integration as inter-area product flows: the internalization of ownership and location factors influencing product flows across MNC units, Management International Review, 41 (3), 233-249.

McDonnell, A., Lavelle, J. \& Gunnigle, P. 2014. Human Resource Management in Late Industrialising Economies: Evidence from Ireland, Management International Review, 54 (3), 361-380.

Morris, S., Wright, P., Trevor, J., Stiles, P., Stahl, G., Snell, S., Paauwe, J. and Farndale, E. 2009. Global challenges to replicating HR: the role of people, processes, and systems, Human Resource Management, 48 (6), 973-995.

Mtar, M. 2010. Institutional, industry and power effects on integration in cross-border acquisitions, Organization Studies, 31 (8), 1099-1127. 
Novicevic, M. \& Harvey, M. 2001. The Changing Role of the Corporate HR Function in Global Organizations of the twenty-first Century, The International Journal of Human Resource Management, 12 (8), 1251-1268.

Royle, T. 2010. 'Low-road Americanization' and the global 'McJob': a longitudinal analysis of work, pay and unionization in the international fast-food industry", Labor History, $51(2), 249-270$.

Schuler, R., Dowling, P. \& DeCieri, H. 1993. An Integrative Framework for Strategic International Human Resource Management, Journal of Management, 19 (2), 419459.

Schuler, R. \& Tarique, I. 2007. International human resource management: a North American perspective, a thematic update and suggestions for future research, The International Journal of Human Resource Management, 18 (5), 717-744.

Smale, A. 2008. Foreign subsidiary perspectives on the mechanisms of global HRM integration, Human Resource Management Journal, 18 (2), 135-153.

Smale, A., Bjorkman, I. \& Sumelius, J. 2012. HRM integration mechanism usage in MNC subsidiaries in China, Personnel Review, 41 (2), 180-199.

Smale, A., Bjorkman, I. \& Sumelius, J. 2013. Examining the differential use of global integration mechanisms across HRM practices: Evidence from China, Journal of World Business, 48, 232-240.

Sparrow, P. 2007. Globalization of HR at Functional Level: Four UK-based Case Studies of the International Recruitment and Selection Process, The International Journal of Human Resource Management, 18 (5), 845-867. 
Taylor, S., Beechler, S. \& Napier, N. 1996. Toward an integrative model of strategic international human resource management, Academy of Management Review, 21 (4), 959-985.

Tempel, A., 2001. The cross-national transfer of human resource management practices in German and British multinational companies. Rainer Hampp Verlag.

Thory, K. 2008. The internationalisation of HRM through reverse transfer: Two case studies of French multinationals in Scotland, Human Resource Management Journal, 18 (1), $54-71$.

Tsai, W. and Ghoshal, S. "Social capital and value creation: The role of intrafirm networks." Academy of Management Journal 41.4 (1998): 464-476.

Tung, R. 1982. Selection and Training Procedures of US, European and Japanese Multinationals, California Management Review, 25 (1), 57-71.

UNCTAD 2016. World Investment Report, United Nations, Geneva.

Wächter, H., Peters, R., Ferner, A., Gunnigle, P. \& Quintanilla, J. 2006. The role of the international personnel function. In: Almond P and Ferner A (eds) American multinationals in Europe. Oxford: Oxford University Press, 248-70.

Wailes, N. (1999) 'The Importance of Small Differences: The Effects of Research Design on the Comparative Study of Industrial Relations Reform in Australia and New Zealand', International Journal of Human Resource Management, 10, 6, 1006-1030.

Watson O’Donnell, S. 2000. Managing Foreign Subsidiaries: Agents of Subsidiaries, or an Interdependent Network? Strategic Management Journal, 21 (5), 525-548. 
Willem, A., Buelens, M. \& Scarbrough, H. 2006. The role of inter-unit coordination mechanisms in knowledge sharing: a case study of a British MNC, Journal of Information Science, 32 (6), 539-561.

Wilson, J. (1995), British Business History, 1720-1994, Manchester: Manchester University Press. 
Table 1: Means and SD $(n=832)$

\begin{tabular}{|c|c|c|}
\hline & Means & $S D$ \\
\hline \multicolumn{3}{|l|}{ Dependent variable } \\
\hline $\begin{array}{l}\text { Centralisation: } \\
\text { IHR committee }\end{array}$ & .6034 & .48949 \\
\hline Global HR philosophy & 3.5156 & 1.32449 \\
\hline $\begin{array}{l}\text { People based integration - HR networking: } \\
\text { IHR regular meetings }\end{array}$ & .5625 & .49638 \\
\hline IHR conferences & .3954 & .48924 \\
\hline IHR task forces & .1815 & .38566 \\
\hline IHR virtual project teams & .4267 & .49489 \\
\hline $\begin{array}{l}\text { Formalisation/Information: } \\
\text { HRIS system }\end{array}$ & .5421 & .49853 \\
\hline Shared HR services & .3365 & .47281 \\
\hline \multicolumn{3}{|l|}{ Controls } \\
\hline Home owned & 2067 & .40520 \\
\hline Ireland & .3125 & .46379 \\
\hline Spain & .3618 & .48080 \\
\hline UK & .3257 & .46893 \\
\hline Sector & .5060 & .50026 \\
\hline 1000-4999 employees worldwide & .2416 & .42830 \\
\hline V30 5000-29999 employees worldwide & .3630 & .48115 \\
\hline V31 30000-59999 employees worldwide & .1250 & .33092 \\
\hline V32 60000+ & .2187 & .41365 \\
\hline \multicolumn{3}{|l|}{ Structure IVs } \\
\hline Inter-firm dependencies in production & 1.240 & .809 \\
\hline Regional structures & .7572 & .42903 \\
\hline Global structures & .6587 & .47445 \\
\hline National subsidiaries & .6142 & .48708 \\
\hline \multicolumn{3}{|l|}{ Country IVs } \\
\hline US & .3473 & .47781 \\
\hline UK & .1214 & .32678 \\
\hline Germany & .0745 & .26277 \\
\hline France & .0769 & .26663 \\
\hline Nordic & .0457 & .20890 \\
\hline Swiss & .0361 & .18655 \\
\hline Spain & .1046 & .30618 \\
\hline Ireland & .0589 & .23557 \\
\hline Netherland & .0252 & .15695 \\
\hline Other Europe & .0276 & .16405 \\
\hline Japan & .0337 & .18045 \\
\hline Rest of World & .0445 & .20626 \\
\hline
\end{tabular}


Table 2: Regression results showing the relationship between country and organisational structure on the three latent variables measuring International HR Integration Functions (with controls)

\begin{tabular}{|c|c|c|c|c|c|c|}
\hline & \multicolumn{2}{|c|}{$\begin{array}{l}\text { Centralisation - } \\
\text { IHR policy comm } \\
\text { and philosophy }\end{array}$} & \multirow{2}{*}{\multicolumn{2}{|c|}{$\begin{array}{c}\begin{array}{c}\text { People-based integration - } \\
\text { International Networking }\end{array} \\
\text { IVs }\end{array}$}} & \multirow{2}{*}{\multicolumn{2}{|c|}{ 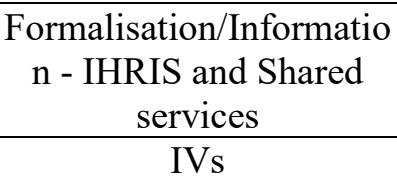 }} \\
\hline & \multirow{2}{*}{$\begin{array}{c}\text { IVs } \\
B\end{array}$} & \multirow[b]{2}{*}{$T$} & & & & \\
\hline & & & $B$ & $T$ & $B$ & $t$ \\
\hline Controls & & & & & & \\
\hline Home owned & .167 & $2.251 *$ & -.134 & $-2.094 *$ & -.004 & -.066 \\
\hline $\begin{array}{l}\text { Country of } \\
\text { operation (UK } \\
\text { reference): } \\
\text { Ireland }\end{array}$ & .046 & -1.194 & .012 & .358 & -.082 & $-2.540^{*}$ \\
\hline Spain & .116 & $2.996 * *$ & -.049 & -1.482 & .140 & $4.264 * * *$ \\
\hline Sector & -.054 & -1.920 & -.031 & -1.269 & -.063 & $-2.538 *$ \\
\hline $\begin{array}{l}\text { Worldwide } \\
\text { employment } \\
\text { (500-4999 } \\
\text { Reference): } \\
\text { 5000-29999 }\end{array}$ & .123 & $3.480 * *$ & .091 & $2.995 * *$ & .107 & $3.518 * * *$ \\
\hline $30000-59999$ & .225 & $4.681 * * *$ & .196 & $4.658 * * *$ & .188 & $4.437 * * *$ \\
\hline $60000+$ & .203 & $4.765 * * *$ & .226 & $5.990 * * *$ & .176 & $4.722 * * *$ \\
\hline Structure IVs & & & & & & \\
\hline $\begin{array}{l}\text { Regional } \\
\text { structure }\end{array}$ & .107 & $3.116^{* *}$ & .052 & 1.752 & .025 & .835 \\
\hline Global structure & .137 & $4.320 * *$ & .105 & $3.802 * * *$ & .090 & $3.257 * *$ \\
\hline $\begin{array}{l}\text { Intra-firm } \\
\text { linkages }\end{array}$ & .071 & $3.858^{* *}$ & .036 & $2.270^{*}$ & .028 & 1.774 \\
\hline $\begin{array}{l}\text { Country IVs } \\
\text { (US reference) }\end{array}$ & & & & & & \\
\hline UK & -.161 & $-2.964 *$ & -.064 & -1.354 & -.117 & $-2.477 * *$ \\
\hline Germany & -.224 & $-4.085 * *$ & -.246 & $-5.057 * * *$ & -.178 & $-3.757 * *$ \\
\hline France & -.125 & $-2.307^{*}$ & -.106 & $-2.238^{*}$ & -.148 & $-3.094 * *$ \\
\hline Nordic & -.051 & -.764 & -.086 & -1.482 & -.212 & $-3.596 * *$ \\
\hline Swiss & -.081 & -1.096 & -.236 & $-3.646 * *$ & -.247 & $-3.773 * *$ \\
\hline Spain & -.211 & $-2.338^{*}$ & -.015 & -.199 & -.119 & -1.538 \\
\hline Ireland & -.104 & -1.052 & .081 & .943 & -.114 & -1.340 \\
\hline Netherland & -.067 & -1.052 & -.189 & $-2.487 *$ & -.295 & $-3.865 * *$ \\
\hline Other Europe & -.233 & $-2.731^{*}$ & -.229 & $-3.118 * *$ & -.308 & $-4.074 * * *$ \\
\hline Japan & -.365 & $\begin{array}{c}- \\
4.479 * * * \\
\end{array}$ & -.382 & $-5.532 * * *$ & -.462 & $-6.223 * * *$ \\
\hline Rest of World & -.061 & -.991 & -.093 & -1.589 & -.146 & $-2.496^{*}$ \\
\hline $\mathrm{R}^{2}$ & $\begin{array}{c}.441 \\
(44 \%)\end{array}$ & & $.272(27 \%)$ & & $.575(57 \%)$ & \\
\hline
\end{tabular}

Model Statistics: $\chi^{2}$ 1730.210; df 204; CFI 0.907; RMSEA 0.037; $n=832$ 
FIGURE 1: Conceptual Model

Figure 1: conceptual model

$\begin{array}{ll}\text { Country of origin } & \\ \begin{array}{l}\text { Organisational } \\ \text { structures }\end{array} & \begin{array}{l}\text { International HR integration } \\ \text { mechanisms: } \\ \text { Centralisation } \\ \text { People based modes } \\ \text { Formalization/information }\end{array} \\ \begin{array}{l}\text { Production } \\ \text { interdependencies }\end{array} & \text { H3 } \\ \end{array}$


Appendix: Means, Standard Deviations (SD), and Correlations

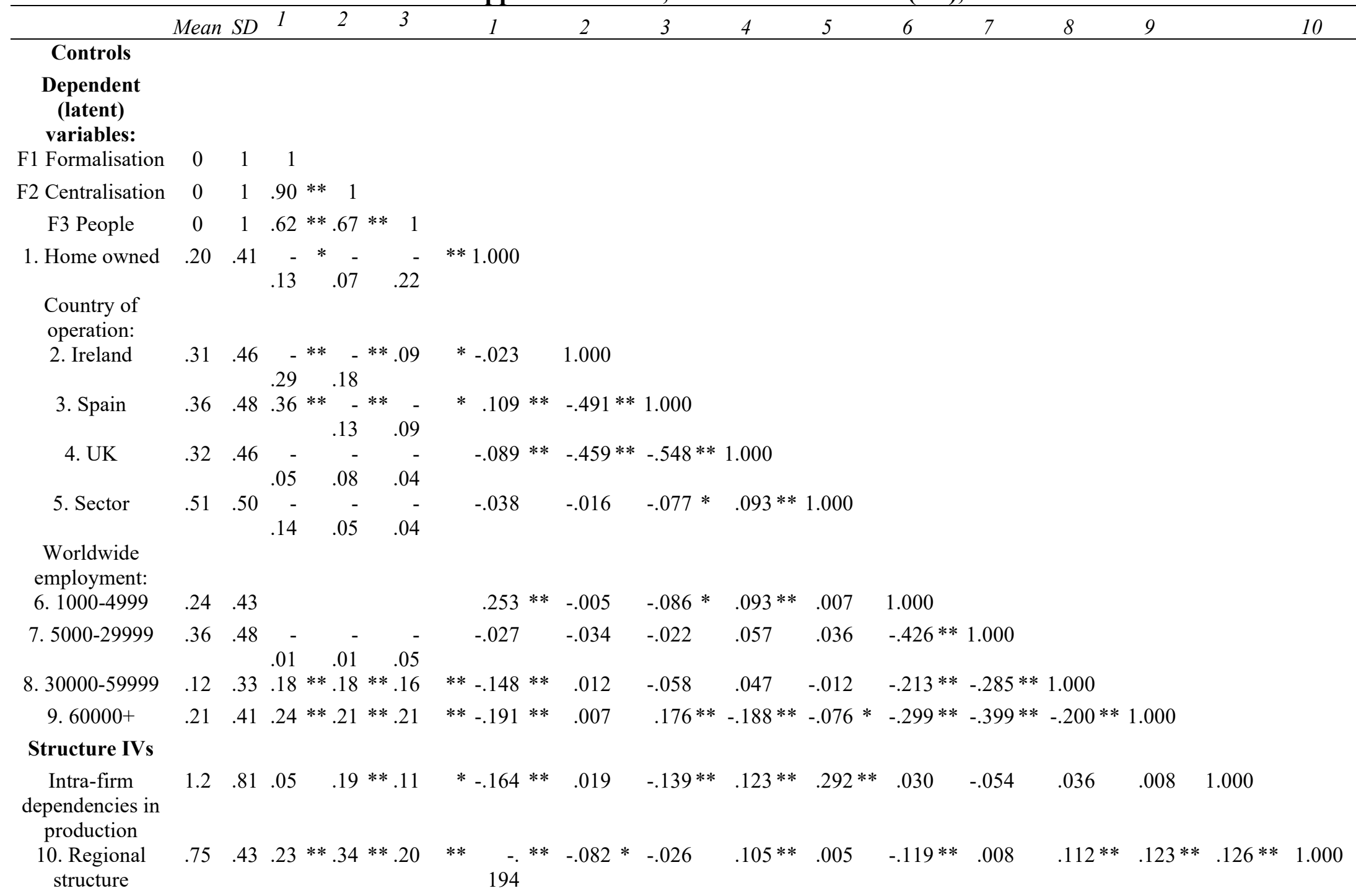




\begin{tabular}{|c|c|c|c|c|c|c|c|c|c|c|c|c|c|c|c|c|c|c|c|c|}
\hline $\begin{array}{l}\text { 11. Global } \\
\text { structure }\end{array}$ & .65 & .47 & .30 & $* * .37$ & $* * .24$ & ** -.177 & $* *$ & $-.083 *$ & .026 & .053 & $.127 * *$ & $-.150 * *$ & .011 & .065 & $.099 * *$ & $.202 * *$ & $.300 * *$ & 1.000 & & \\
\hline $\begin{array}{l}\text { 12. National } \\
\text { structure }\end{array}$ & .61 & .48 & .19 & $* * .17$ & $* * .10$ & $* .092$ & $* *$ & $-.106 * *$ & $.133 * *$ & -.034 & -.051 & -.066 & .008 & .023 & .067 & .046 & .065 & $.157 * *$ & 1.000 & \\
\hline \multicolumn{21}{|l|}{ Country IVS } \\
\hline 13. US & .34 & .48 & .39 & $* * .27$ & $* * .32$ & $* *-.363$ & $* *$ & .049 & $-.127 * *$ & $.083 *$ & .017 & $-.133 * *$ & -.010 & $.141 * *$ & .043 & $.099 * *$ & $.142 * *$ & $.127 * *$ & $-.070 *$ & 1.000 \\
\hline 14. UK & .12 & .33 & .05 & .08 & .04 & .206 & $* *$ & .034 & $-.093 * *$ & .062 & $-.097 * *$ & .057 & -.013 & -.029 & -.001 & -.044 & -.007 & -.056 & -.024 & $-.269 * *$ \\
\hline 15. Germany & .07 & .26 & .04 & & .11 & $*-.141$ & $* *$ & -.008 & .060 & -.054 & .031 & .011 & -.062 & .017 & .049 & $.097 * *$ & -.030 & .032 & -.003 & $-.212 * *$ \\
\hline 16. France & .08 & .27 & .02 & .- & .01 & -.144 & $* *$ & $-.123 * *$ & $.113 * *$ & .003 & -.003 & -.036 & -.021 & -.014 & $.098 * *$ & -.041 & .023 & -.033 & .030 & $-.215 * *$ \\
\hline 17. Nordic & .05 & .21 & .08 & .02 & .01 & -.107 & $* *$ & -.044 & -.043 & $.085 *$ & .031 & .038 & .014 & .004 & -.046 & .043 & .012 & .055 & .046 & $-.160 * *$ \\
\hline 18. Switzerland & .04 & .19 & .07 & .04 & .04 & -.098 & $* *$ & .001 & -.019 & .018 & .022 & -.034 & -.012 & .063 & .022 & .035 & $.074 *$ & $.083 *$ & -.014 & $-.147 * *$ \\
\hline 19. Spain & .10 & .31 & .05 & .01 & $\begin{array}{r}- \\
.16\end{array}$ & $* * \quad .630$ & $* *$ & $-.203 * *$ & $.398 * *$ & $-.211 * *$ & -.037 & $.128 * *$ & .003 & $-.094 * *$ & $-.095 * *$ & $-.182 * *$ & $-.117 * *$ & -.054 & $.139 * *$ & $-.242 * *$ \\
\hline 20. Ireland & .06 & .24 & .24 & $\begin{array}{rr}* * & - \\
& 13\end{array}$ & $\begin{array}{rr}* * & - \\
.06\end{array}$ & .465 & $* *$ & $.354 * *$ & $-.185 * *$ & $-.152 * *$ & -.027 & $.157 * *$ & -.051 & $-.095 * *$ & $-.120 * *$ & $-.078 *$ & $-.214 * *$ & $-.217 * *$ & -.046 & $-.178 * *$ \\
\hline 21. Netherlands & .03 & .16 & .12 & $* .01$ & .03 & -.082 & $*$ & .031 & -.013 & -.016 & .012 & -.019 & .006 & -.038 & .063 & -.058 & .064 & .005 & .015 & $-.123 * *$ \\
\hline 22. Other Europe & .03 & .16 & .15 & .01 & $\begin{array}{rr}* * & - \\
& .01\end{array}$ & $*-.090$ & $* *$ & .008 & .017 & -.024 & -.021 & -.027 & .056 & -.019 & -.036 & -.008 & $-.085 *$ & $-.079 *$ & .026 & $-.135 * *$ \\
\hline 23. Japan & .03 & .18 &. & $\begin{array}{r}- \\
.17\end{array}$ & ** $\quad-$ & ** -.099 & $* *$ & $-.079 *$ & -.035 & $.112 * *$ & $.085 *$ & -.059 & .067 & -.050 & .046 & $.097 * *$ & -.017 & -.011 & -.033 & $-.149 * *$ \\
\hline 24. Rest of world & .04 & .21 & .03 & .01 & .02 & -.102 & $* *$ & -.010 & $-.066 *$ & $.077 *$ & .037 & -.040 & $.092 * *$ & -.011 & -.044 & .001 & .055 & .057 & -.023 & $-.153 * *$ \\
\hline
\end{tabular}




\begin{tabular}{lllllllllll}
\hline 14 & 15 & 16 & 17 & 18 & 19 & 20 & 21 & 22 & 23 & 24 \\
\hline
\end{tabular}

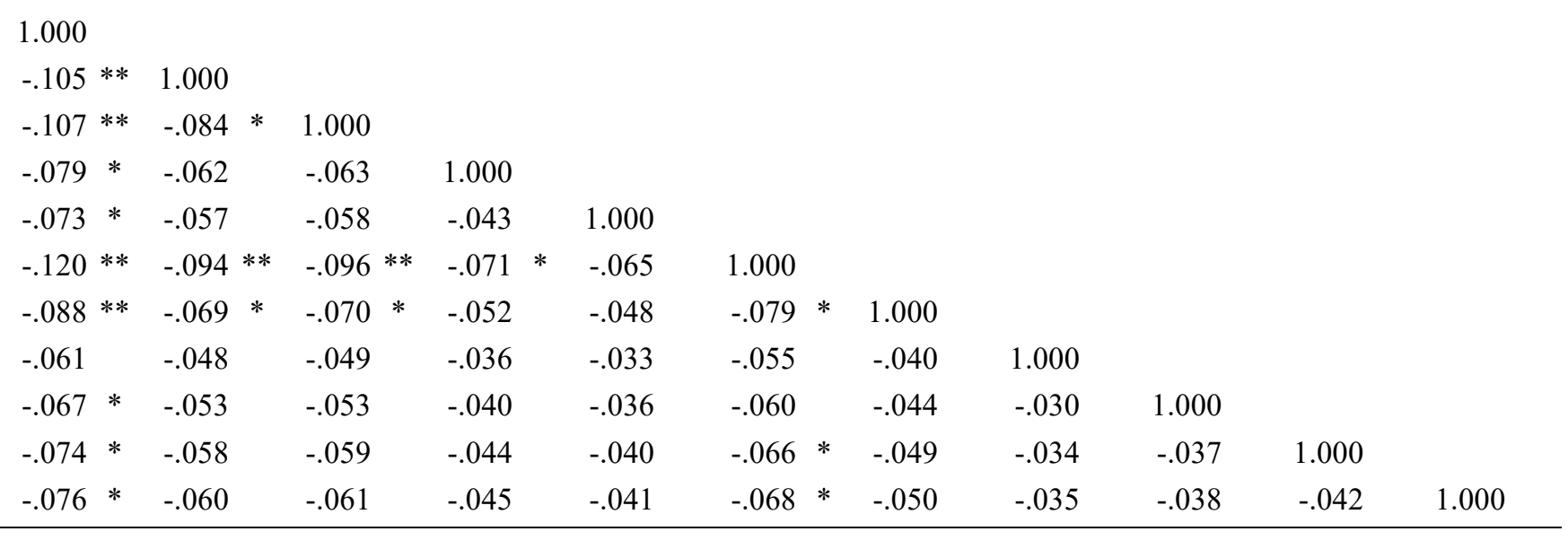


